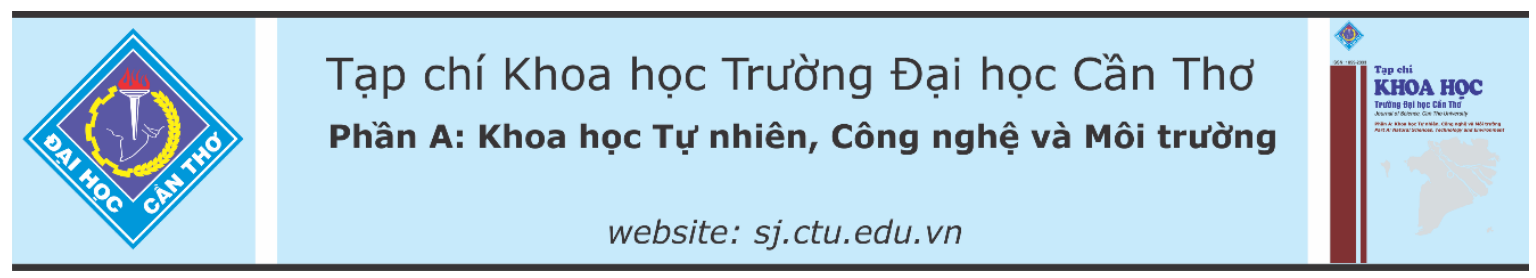

DOI:10.22144/ctu.jvn.2021.010

\title{
ĐÁNH GIÁ BIẾN ĐỘNG RÙ̀NG NGẬP MẬN TỈNH TIỀN GIANG TRÊN CƠ SỞ ẢNH VỆ TINH GIAI ĐOẠN 1988-2018
}

\author{
Phùng Thái Dương* và Tôn Sơn \\ Truờng Đại học Đồng Tháp \\ *Nguròi chịu trách nhiệm về bài viết: Phùng Thái Dương (email: phungthaiduongdht@gmail.com)
}

\section{Thông tin chung:}

Ngày nhận bài: 06/08/2020

Ngày nhận bài sưa: 16/11/2020

Ngày duyệt đăng: 27/03/2021

\section{Title:}

Assessment of mangrove forest change in Tien Giang province using satellite images in the period of 1988-2018

\section{Tù khóa:}

Anh viến thám Landsat, rùng ngập mặn, Tiền Giang

\section{Keywords:}

Landsat remote sensing images, mangrove forest, Tien Giang

\begin{abstract}
In this study, Landsat 5-TM, 8-OLI remote sensing image data and classification method of Maximum Likelihood Classifier - MCL were used to classify and assess the changes in the area of mangrove forests in Tien Giang province over the period 1988-2018. The results of the image interpretation in 1988, 1998, 2013, 2018 and the overlapping of the mangrove maps over stages show the area of mangroves in Tien Giang province decreased continuously from 1988 to 2013, then increased from 2013 to 2018. If considering the period of 30 years from 1988 to 2018, the total area of mangroves in Tien Giang province was decreased by $12,4 \%$ compared to the beginning, from 1.761,8 ha in 1988 reduced to 1.543,5 ha in 2018, decreasing by 218,4 ha. The recovery rate of mangroves is determined to be 36 ha/year, lower than their disappearance rate in this period (43 ha/year). Mangroves are restored mainly from coastal seawater surface (accounting for 66.6\%); planting mangroves in abandoned shrimp ponds, or planting mangroves in combination with aquaculture (accounting for 27.6\%).
\end{abstract}

\section{TÓM TÁ́T}

Trong nghiên cứu này, tu liệu ảnh viễn thám Landsat 5-TM, 8-OLI và phuoong pháp phân loại có kiểm định Maximum Likelihood Classifier $M C L$ được sử dụng để phân loại và đánh giá biến động diện tích rùng ngập mặn (RNM) tỉnh Tiền Giang giai đoạn 1988-2018. Kết quả giải đoán ảnh viễn thám năm 1988, 1998, 2013, 2018 và kết quả chồng xếp các bản đồ rù̀ng ngập mặn qua các giai đoạn cho thấy diện tích RNM ở Tiền Giang giảm liên tục tù̀ năm 1988 đến năm 2013, sau đó tăng tù̀ năm 2013 đến năm 2018. Nếu xét trong khoảng thời gian 30 năm tù 1988 đến 2018, tổng diện tích RNM ở Tiền Giang đã giảm 12,4\% so với ban đầu, với 1.761,8 ha năm 1988 giảm xuống còn 1.543,5 ha năm 2018, giảm đi 218,4 ha. Tốc độ phuc hồi của RNM được xác định là 36 ha/năm, thấp hơn so với tốc độ biến mất của chúng trong giai đoạn 1988-2018 (43 ha/năm). RNM được phuc hồi chủ yếu tù mặt nước biển ven bò̀ (chiếm 66,6\%); trồng mói RNM trong các ao nuôi tôm bị bỏ hoang, hoặc trồng RNM kết hợp với nuôi trồng thủy sản (NTTS) (chiếm 27,6\%). 


\section{1. ĐẶT VẤN ĐỀ}

Tiền Giang là tỉnh duyên hải của Đồng bằng sông Cửu Long (ĐBSCL), phía Đông tiếp giáp Biển Đông với đường bờ biển dài khoảng $32 \mathrm{~km}$, trong đó có $21 \mathrm{~km}$ thuộc huyện Gò Công Đông và $11 \mathrm{~km}$ thuộc huyện Tân Phú Đông. Trước năm 2000, bên ngoài đê biển của tỉnh Tiền Giang đã từng có một đai rừng ngập mặn phòng hộ khá dày từ 100-800 m. Rừng ngập mặn (RNM) có vai trò quan trọng trong việc bảo vệ bờ biển, ngăn chặn gió bão, hạn chế xói lở, mở rộng diện tích đất liền và điều hòa khí hậu (Phạm Văn Ngọt, 2012). Tuy nhiên, trong những năm gần đây, do nhiều nguyên nhân khác nhau, rừng phòng hộ ven biển tỉnh Tiền Giang đã bị suy thoái dần và có nơi bị mất trắng. Các kết quả phân tích ảnh vệ tinh cho thấy bờ biển Gò Công Đông (từ Vàm Láng đến Tân Thành) đã bị xói lở nghiêm trọng với tốc độ xói từ 10-15 m/năm, làm mất nhiều diện tích RNM, đe dọa sản xuất và đời sống của người dân (Bùi Trọng Vinh, 2016).

Tư liệu ảnh viễn thám Landsat với tính ưu việt là nguồn tư liệu cung cấp thông tin bề mặt Trái đất với tính chất bao phủ rộng, thông tin khách quan và lặp lại theo chu kỳ. Vì vậy, tư liệu ảnh này được sử dụng rộng rãi trong nhiều lĩnh vực, trong đó có giám sát biến động lớp phủ rừng (Nardin et al., 2016; Nguyễn Hải Hòa, Nguyễn Văn Quốc, 2017; Pham Hong Tinh et al., 2019). Đã có nhiều công trình nghiên cứu sử dụng ảnh vệ tinh để đánh giá biến động diện tích RNM ở Tiền Giang cho kết quả khá chính xác và khách quan, tiêu biểu như:

"Phân tích diễn biến rừng bằng ảnh viễn thám tại Cồn Ngang, huyện Tân Phú, tỉnh Tiền Giang (Trần Vũ Khánh Linh, Viên Ngọc Nam, 2017)”. Nghiên cứu đã sử dụng ảnh viễn thám Landsat, tính các chỉ số NDVI, RVI, DVI, LAI kết hợp với tổ hợp màu tự nhiên để tiến hành phân loại ảnh qua các năm 2001, 2004, 2007, 2010, 2013 và 2016. Từ đó phân tích quá trình hình thành Cồn Ngang và RNM từ năm 2001 đến năm 2016. Như vậy, nghiên cứu này không đánh giá biến động diện tích RNM trên toàn tỉnh Tiền Giang, mà chỉ nghiên cứu tại Cồn Ngang, huyện Tân Phú.

"Sử dụng ảnh viễn thám Landsat và DSAS 4.3 (Digital Shoreline Analysis System) để đánh giá một cách định lượng tốc độ biến động đường bờ biển Gò Công Đông (Tiền Giang) từ năm 1991 đến năm 2014 (Bùi Trọng Vinh, 2016)". Đồng thời, các mẫu trầm tích, mẫu nước biển ven bờ được thu thập và phân tích nhằm tìm kiếm nguyên nhân gây xói lở khu vực này. Có thể thấy, sự biến đổi đường bờ biển gây ra sự suy thoái RNM phòng hộ ven biển trên toàn tỉnh Tiền Giang chưa được đánh giá đầy đủ.

Quá trình phân tích cho thấy, các nghiên cứu trên chỉ tập trung đánh giá biến động diện tích RNM của một khu vực có diện tích nhỏ, vì vậy kết quả thu được chưa phản ánh sự biến đổi về diện tích và sự phân bố không gian của RNM trên toàn tỉnh Tiền Giang. Nguyên nhân dẫn đến sự biến động đã phần nào được xác định, tuy nhiên quá trình phục hồi của RNM chưa được đề cập. Do đó, việc sử dụng ảnh viễn thám Landsat đa thời gian để đánh giá biến động diện tích RNM tỉnh Tiền Giang giai đoạn 1988-2018 là việc làm cấp thiết và có ý nghĩa khoa học. Kết quả nghiên cứu xác định sự biến đổi về mặt không gian của RNM sau 30 năm, nguyên nhân dẫn đến sự suy giảm diện tích RNM, quá trình phục hồi của chúng qua các giai đoạn khác nhau. Từ đó giúp cho các nhà hoạch định chính sách có thể đề ra các giải pháp khôi phục và phát triển hệ sinh thái RNM, góp phần phục hồi và làm phong phú thêm các hệ sinh thái đa dạng ven biển.

\section{DŨ LIÊ̂U VÀ PHƯƠNG PHÁP NGHIÊN CúU}

\subsection{Dữ liệu}

Sử dụng ảnh viễn thám Landsat $5 \mathrm{TM}$ và Landsat 8 OLI để giải đoán và thành lập các bản đồ hiện trạng RNM năm 1988, 1998, 2013 và 2018 và bản đồ biến động diện tích RNM tỉnh Tiền Giang qua các giai đoạn 1988-1998, 1998-2013, 2013-2018 và 1988-2018. Để giảm thiểu ảnh hưởng của mây, ưu tiên sử dụng ảnh được chụp vào mùa khô (từ tháng 11-tháng 4), thời gian ảnh được chụp phù hợp với thời gian cần đánh giá, nhưng do số lượng ảnh hạn chế nên việc sử dụng ảnh có sai khác không nhiều về thời gian là hoàn toàn chấp nhận được. Nghiên cứu này không đánh giá biến động diện tích RNM Tiền Giang giai đoạn 1998-2008, vì ảnh vệ tinh năm 2008 bị lỗi sọc ảnh nên chất lượng không đảm bảo. Thông tin về ảnh vệ tinh được thể hiện trong Bảng 1. 
Bảng 1. Dữ liệu ảnh Landsat được sử dụng để nghiên cứu

\begin{tabular}{lcccl}
\hline Mã ảnh & \multirow{3}{*}{ Mây } & \multicolumn{3}{c}{ Chất lượng Độ phân giải } \\
ảnh & (m) & Ngày chụp \\
\hline LT05_L1TP_125053_19880130_20170209_01_T1 & $1 \%$ & 7 & $30 \mathrm{~m}$ & $30 / 01 / 1988$ \\
LT05_L1TP_125053_19980109_20170111_01_T1 & $0 \%$ & 9 & $30 \mathrm{~m}$ & $9 / 01 / 1998$ \\
LC08_L1TP_125053_20140222_20170425_01_T1 & $1,98 \%$ & 9 & $30 \mathrm{~m}$ & $22 / 02 / 2014$ \\
LC08_L1TP_125053_20181031_20181031_01_RT & $6,25 \%$ & 9 & $30 \mathrm{~m}$ & $31 / 10 / 2018$ \\
\hline
\end{tabular}

Nguồn: http://earthexplorer.usgs.gov

\subsection{Phương pháp nghiên cứu}

Các bước nghiên cứu được thể hiện trên sơ đồ Hình 2.

\subsubsection{Phuoong pháp thực địa}

Trước khi tiến hành giải đoán ảnh viễn thám đã có chuyến khảo sát thực địa tại 8 địa điểm chính có RNM ở tỉnh Tiền Giang vào ngày 9/3/2018 (Hình 1). Các điểm khảo sát phân bố dọc theo bờ biển khu vực nghiên cứu, đặc trưng cho RNM ven biển tỉnh
Tiền Giang. Quá trình khảo sát có sử dụng Hệ thống định vị toàn cầu GPS. Đồng thời, để đánh giá tỉ lệ chính xác của kết quả phân loại, tiến hành đợt thực địa bổ sung vào ngày $27 / 2 / 2019$. Quá trình thực địa đã thu thập tọa độ địa lý của 33 điểm mẫu cho 5 loại lớp phủ, rải đều trên toàn bộ khu vực nghiên cứu. Các điểm mẫu này được lựa chọn ngầu nhiên, không trùng với các điểm nghiên cứu trong đợt 1 , được sử dụng để đánh giá tî̉ lệ chính xác của kết quả phân loại.

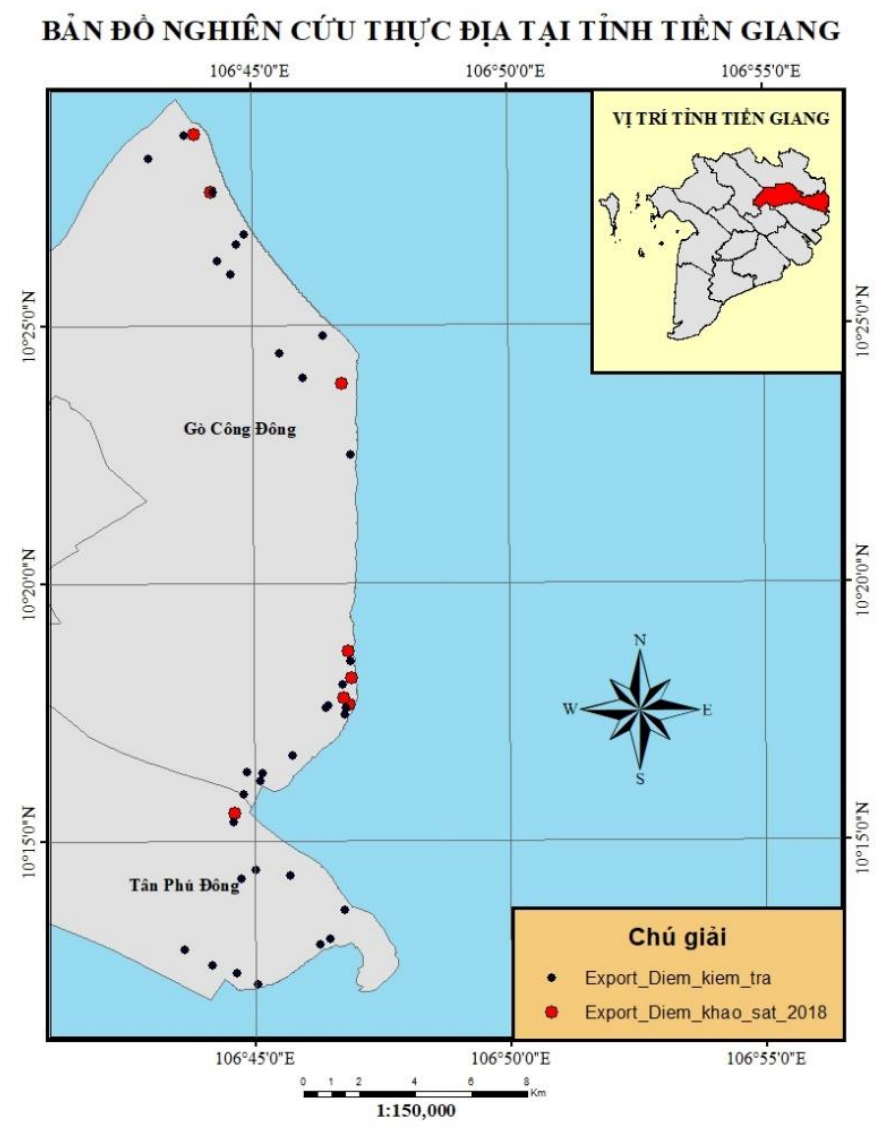

Hình 1. Bản đồ các điểm nghiên cứu thực địa tại tỉnh Tiền Giang 


\subsubsection{Phuoong pháp xử lý ảnh vệ tinh}

Tiền Giang có diện tích tự nhiên $2.484,2 \mathrm{~km}^{2}$. RNM phân bố chủ yếu dọc theo bờ biển và các vùng ven biển của các huyện Tân Phú Đông và Gò Công Đông. Trên các ảnh vệ tinh, RNM được phát hiện bởi các đặc điểm quang phổ trong phạm vi của các bước sóng hồng ngoại nhìn thấy, hồng ngoại gần và sóng ngắn. Việc đánh giá độ tin cậy của các dấu hiệu trên ảnh viễn thám được thực hiện trên cơ sở thông tin từ các điểm khảo sát thực địa. Phân tích thông tin vệ tinh cho phép xác định ranh giới của RNM tỉnh Tiền Giang vào các năm 1988, 1998, 2013 và 2018. Diện tích của khu vực nghiên cứu sau khi chồng xếp các bản đồ là $14.518,1$ ha.

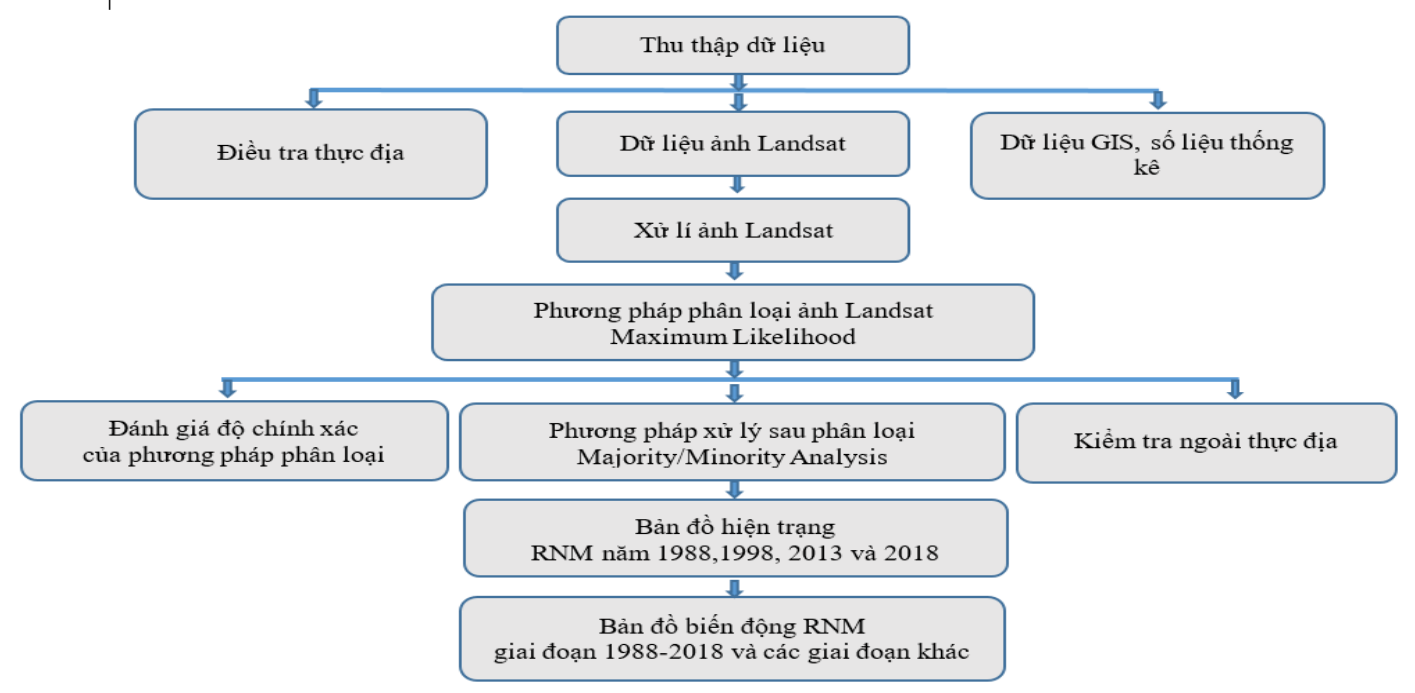

Hình 2. So đồ các bước xử lý và phân loại ảnh Landsat

2.2.3. Hệ thống phân loại thực phủ khu vục nghiên cứu

Căn cứ vào kết quả khảo sát thực địa, hệ thống phân loại lớp phủ mặt đất của khu vực nghiên cứu được chia ra làm 5 loại: RNM, đất nông nghiệp, mặt nước, nuôi trồng thủy sản (NTTS), và đất khác (Bảng 2).

\section{Bảng 2. Hệ thống phân loại thực phủ khu vực nghiên cứu}

\begin{tabular}{|c|c|c|c|}
\hline TT & Loại thực phủ & Miêu tả & Ảnh thực địa \\
\hline 1 & RNM & $\begin{array}{l}\text { Đất có độ che phủ rừng từ } 10 \% \text { trở lên, bao gồm các } \\
\text { loài đặc trưng của RNM. }\end{array}$ & \\
\hline 2 & Đất nông nghiệp & Khu vực trồng lúa, rau màu, cây lâu năm,... & \\
\hline 3 & Mặt nước & Sông, ao, hồ, đầm lầy và mặt nước biển. & \\
\hline 4 & NTTS & $\begin{array}{l}\text { Mặt nước trong các ao nuôi nhân tạo, kết hợp với bờ } \\
\text { ao và các dãy rừng ngập mặn. }\end{array}$ & \\
\hline 5 & Đất khác & Đất khu dân cư, giao thông, đất trống,... & \\
\hline
\end{tabular}




\subsubsection{Khóa giải đoán cho khu vực nghiên cứu}

Để thực hiện tốt quá trình giải đoán phải xây dựng được khóa giải đoán cho từng loại lớp phủ, nó giúp cho việc lựa chọn mẫu phân loại sau này được chính xác. Trong bài viết này, khóa giải đoán được xây dựng cho 5 loại lớp phủ mặt đất trong khu vực nghiên cứu của tỉnh Tiền Giang dựa trên các tổ hợp màu khác nhau (Bảng 3).

\section{Bảng 3. Khóa giải đoán cho khu vực nghiên cứu}

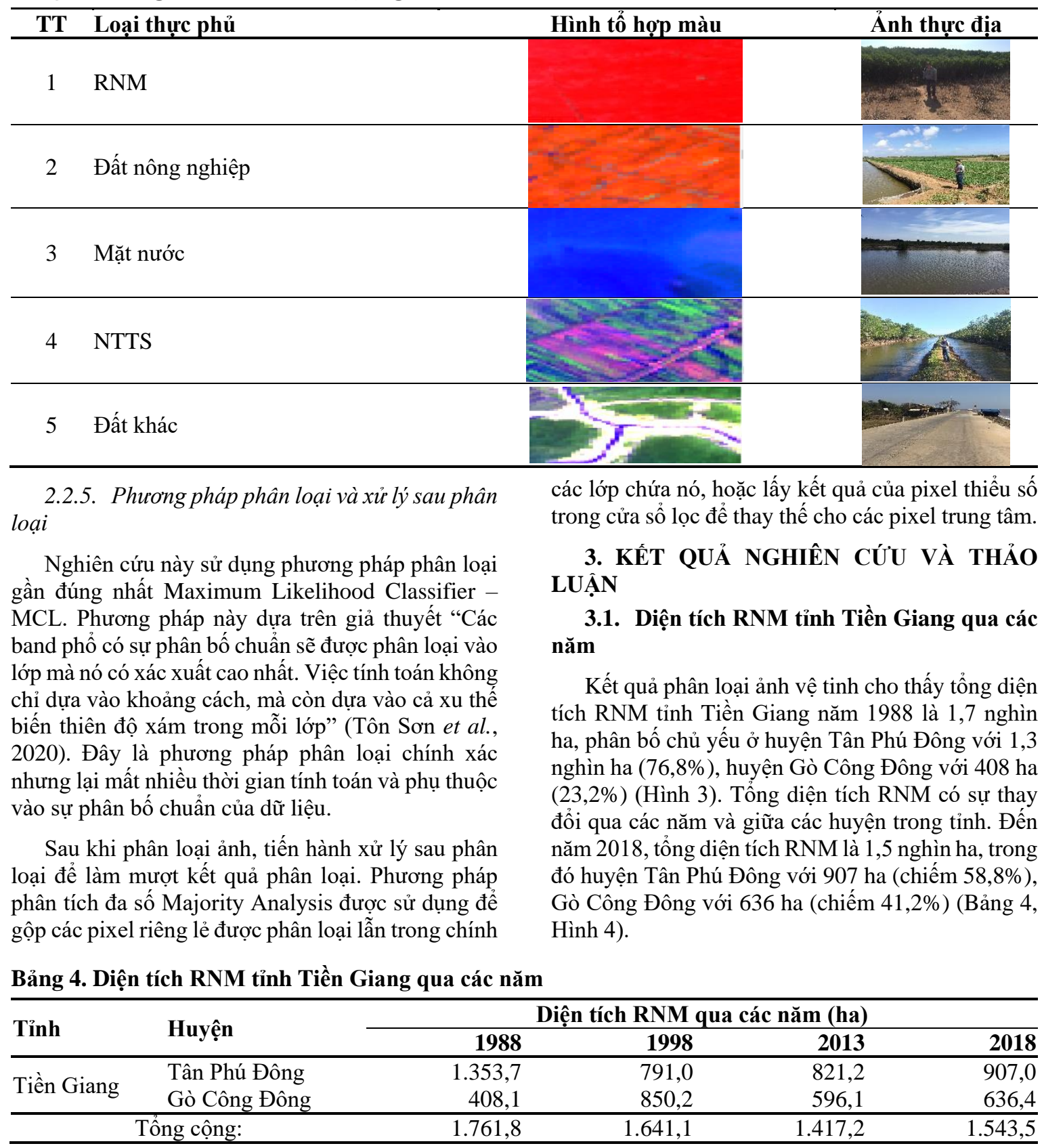




\section{BẢN ĐỒ RÙ̉NG NGẬP MặN TỈNH TIỂN GIANG NĂM 1988}

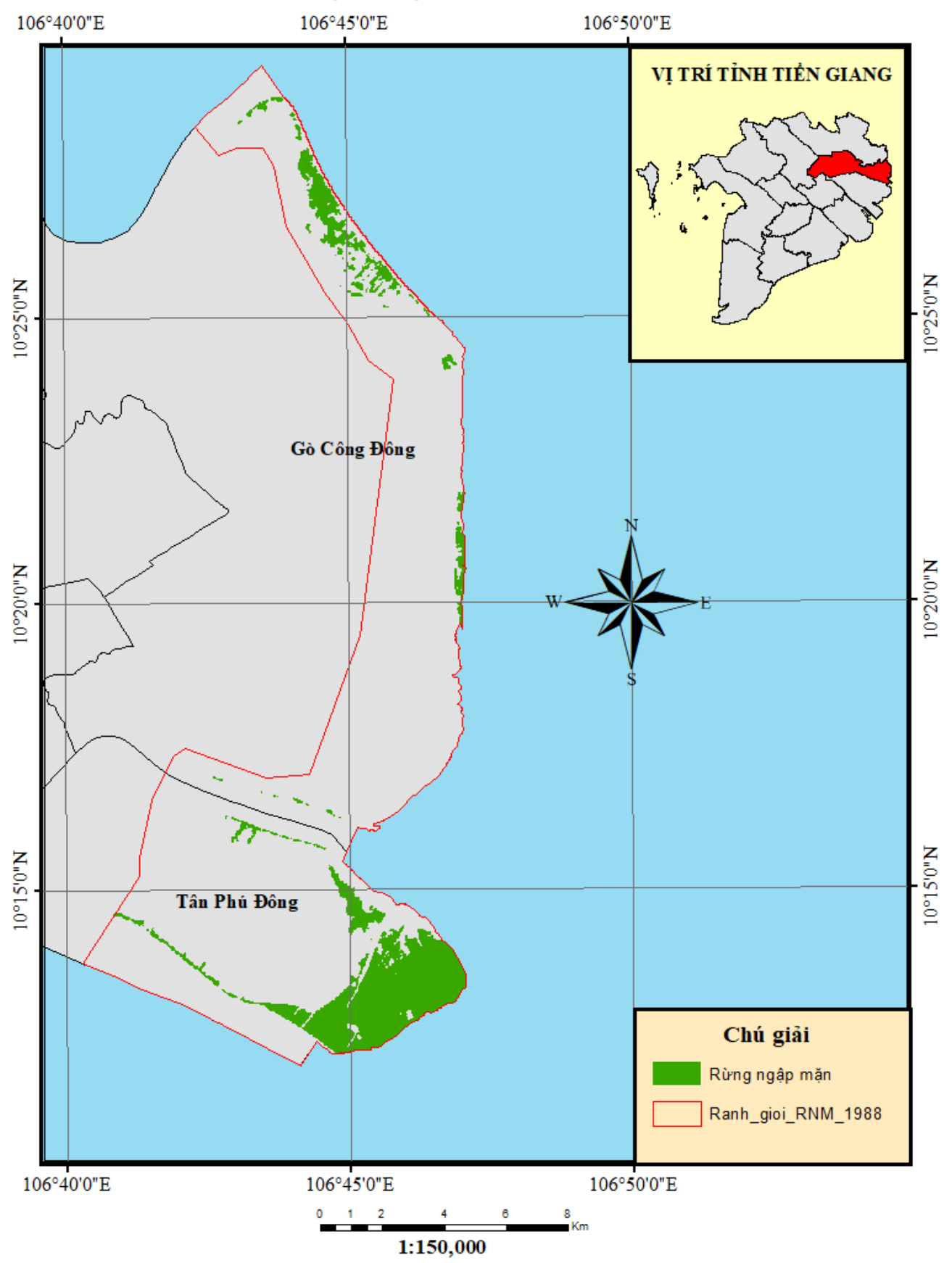

Hình 3. Bản đồ RNM tỉnh Tiền Giang năm 1988 


\section{BẢN ĐỒ RÙ̉NG NGẬP MẶN TỈNH TIỀN GIANG NĂM 2018}

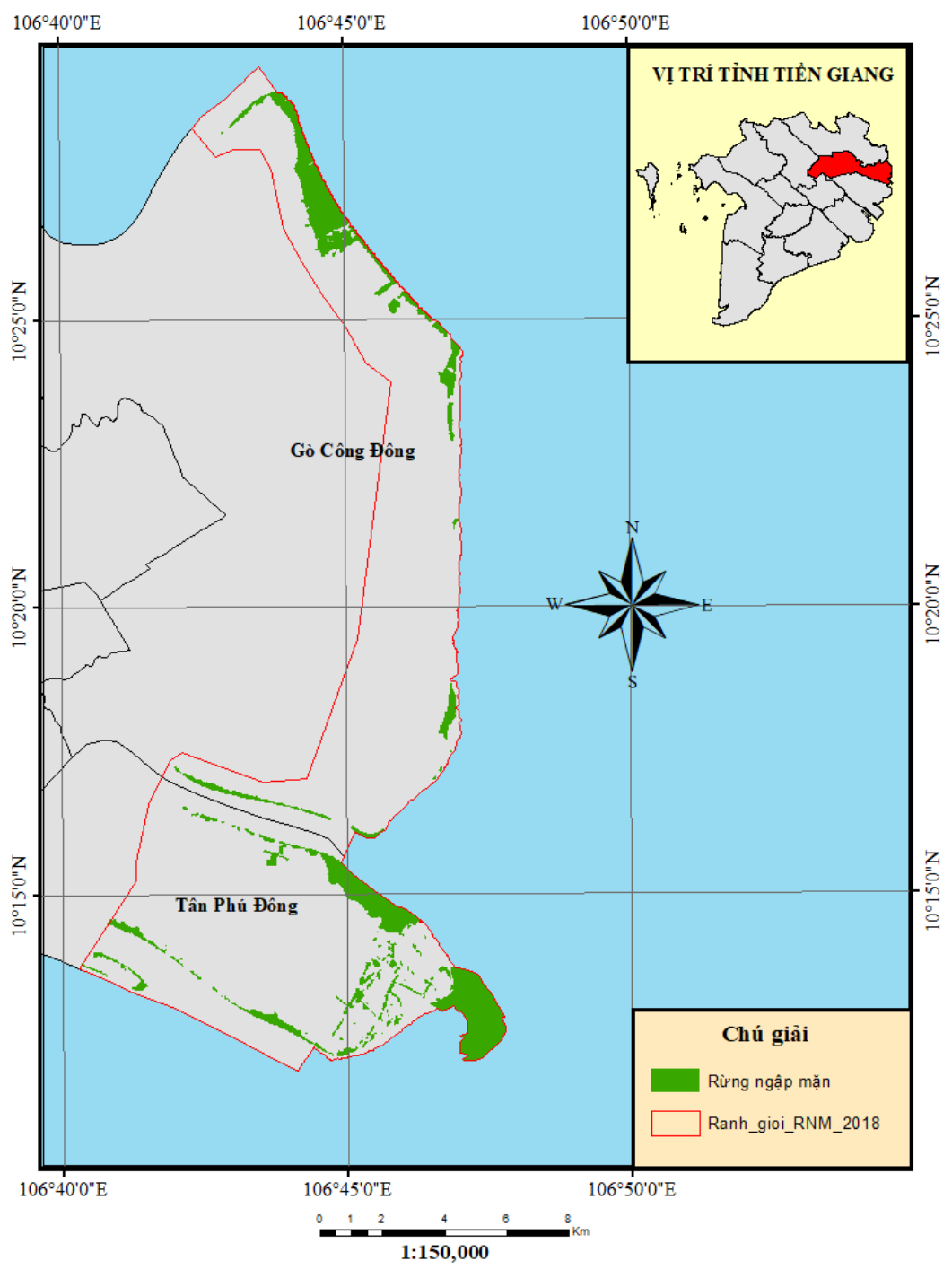

Hình 4. Bản đồ RNM tỉnh Tiền Giang năm 2018

3.2. Biến động diện tích RNM tỉnh Tiền Giang giai đoạn 1988-2018

\subsubsection{Biến đổi tổng diện tích RNM}

Sau 30 năm (1988-2018), diện tích RNM tỉnh Tiền Giang giảm 218 ha, hay giảm $12,4 \%$ so với diện tích RNM năm 1988. Mức độ biến đổi diện tích RNM có sự khác nhau giữa các huyện trong tỉnh; huyện Tân Phú Đông có diện tích RNM bị suy giảm nhiều nhất với 446 ha, trong khi đó diện tích RNM ở huyện Gò Công Đông lại tăng lên 228 ha (Bảng 5, Hình 5).

Bảng 5. Biến đổi diện tích RNM Tiền Giang giai đoạn 1988-2018

\begin{tabular}{llrrr}
\hline \multirow{2}{*}{ Tỉnh } & \multirow{2}{*}{ Huyện } & \multicolumn{2}{c}{ Diện tích RNM (ha) } & \multicolumn{1}{c}{ Giai đoạn } \\
\cline { 3 - 5 } & Nầm 1988 & Năm 2018 & 1988-2018 (ha) \\
\hline \multirow{2}{*}{ Tiền Giang } & Tân Phú Đông & $1.353,7$ & 907,0 & $-446,7$ \\
& Gò Công Đông & 408,1 & 636,4 & 228,3 \\
\hline & Tồng cộng: & $1.761,8$ & $1.543,5$ & $-218,4$ \\
\hline
\end{tabular}


Tuy nhiên, nếu xét trong các mốc thời gian cụ thể thì xu hướng biến đổi RNM khác nhau: diện tích
RNM giảm từ năm 1988 đến 2013, sau đó tăng từ năm 2013 đến năm 2018 (Hình 6).

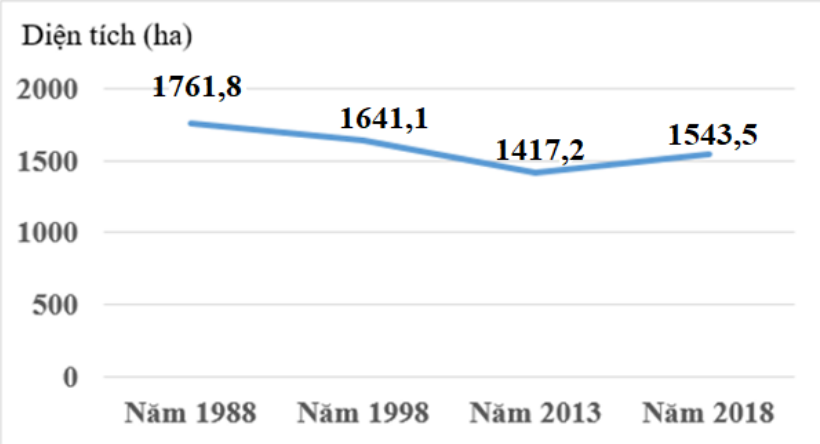

Hình 6. Biểu đồ biến đổi diện tích RNM tỉnh Tiền Giang qua các năm
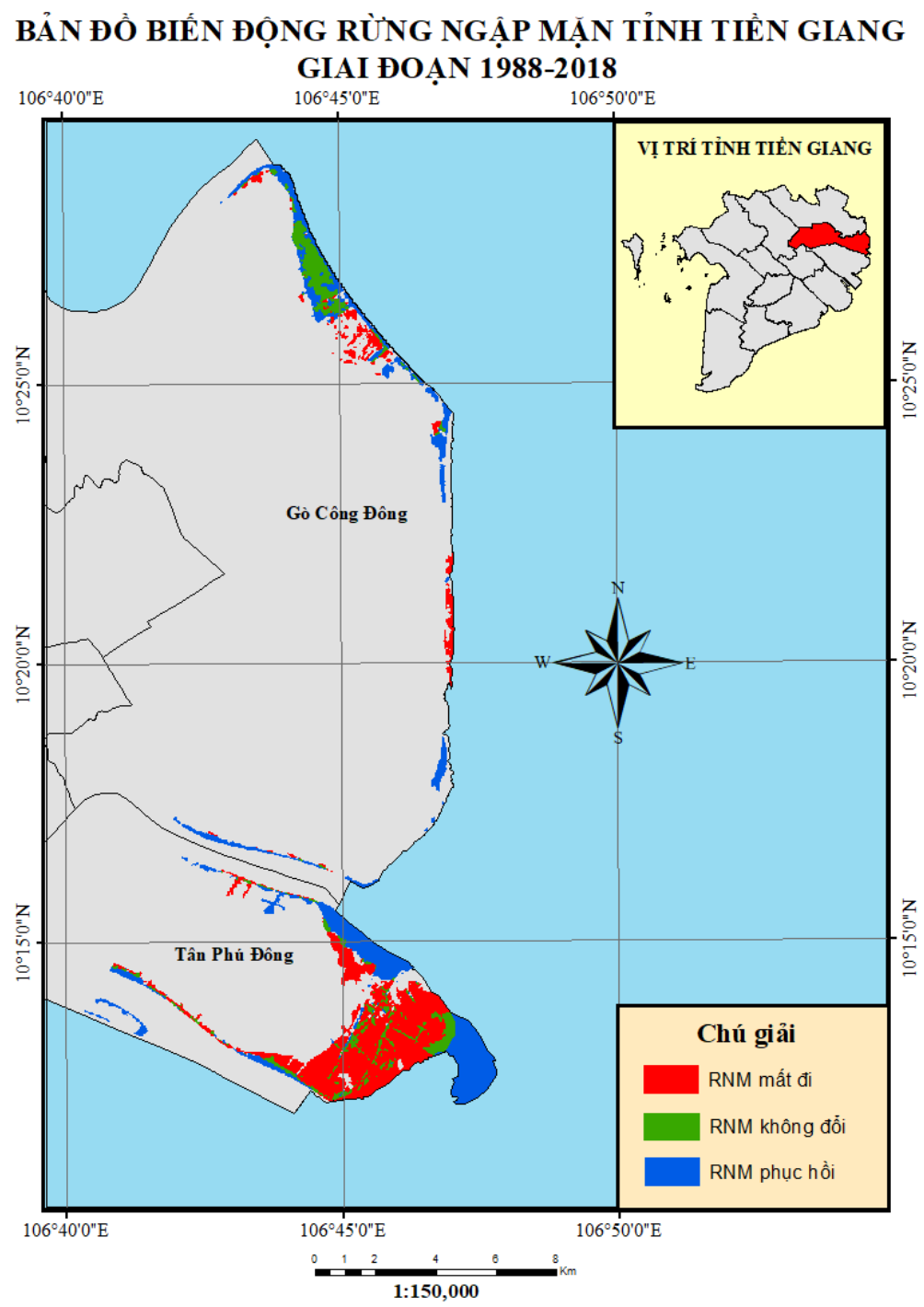

Hình 5. Bản đồ biến động RNM tỉnh Tiền Giang giai đoạn 1988-2018 


\subsubsection{Tốc độ biến đổi diện tích RNM}

Trong khoảng thời gian 30 năm (1988-2018), diện tích RNM ở tỉnh Tiền Giang giảm 218 ha $(7,3$ ha/năm), hay giảm $0,4 \%$ /năm so với diện tích RNM năm 1988. Trong từng giai đoạn cụ thể, tốc độ biến đổi diện tích RNM có sự khác nhau. Giai đoạn 19881998, RNM suy giảm trên diện tích 120 ha (12 ha/năm). Giai đoạn 1998-2013, RNM suy giảm trên diện tích 223 ha (15 ha/năm). Tuy nhiên, sang giai đoạn 2013-2018 diện tích RNM tăng 126 ha (25 ha/năm) (Hình 7). Sự biến đổi diện tích RNM ở Tiền Giang trong từng giai đoạn là kết quả của hai quá trình đối ngược nhau: biến mất (RNM chuyển sang các loại đất khác) và phục hồi RNM (quá trình ngược lại).

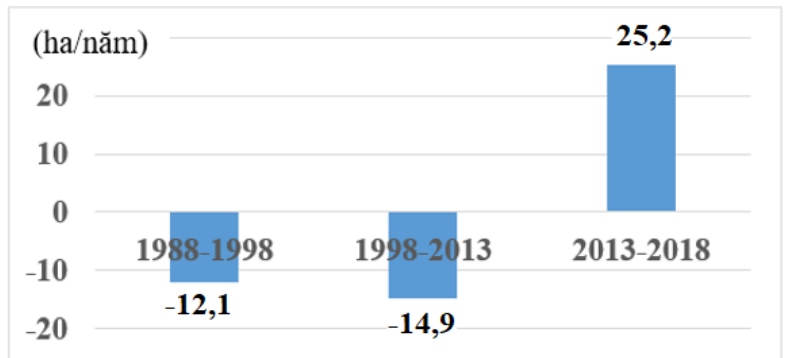

\section{Hình 7. Tốc độ biến đổi diện tích RNM tỉnh Tiền Giang qua các giai đoạn}

3.2.3. Diện tich RNM bị biến mất ở tỉnh Tiền Giang giai đoạn 1988-2018

Bảng 6 cho thấy, giai đoạn 1988-2018 RNM tỉnh Tiền Giang bị biến mất trên diện tích 1,3 nghìn ha
(43 ha/năm), hay 74,2\% diện tích RNM năm 1988 bị mất đi trong giai đoạn này. Trong các giai đoạn cụ thể, sự biến mất của RNM có sự biến đồi theo xu hướng giảm dần theo thời gian, điều đó được thể hiện trong Hình 8.

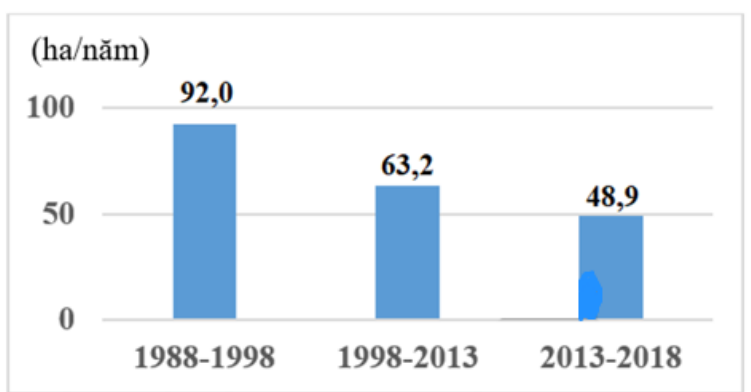

\section{Hình 8. Tốc độ biến mất của RNM tỉnh Tiền Giang qua các giai đoạn}

Nguyên nhân chính dẫn đến sự suy giảm diện tích RNM là do sự chuyển đổi từ RNM sang NTTS với 824 ha, chiếm 63,1\% tổng diện tích RNM bị mất đi trong giai đoạn 1988-2018. Tiếp đến là sự suy giảm diện tích RNM do sạt lở bờ biển với 413 ha, chiếm $31,6 \%$. Diện tích chuyển đổi từ RNM sang đất nông nghiệp và các loại đất khác không nhiều, chỉ với 70 ha, chiếm 5,4\% (Trần Thị Lợi \& Phạm Minh Cương, 2015) (Bảng 6). Trong từng giai đoạn cụ thể 1988-1998, 1998-2013, và 2013-2018, sự suy giảm diện tích RNM do chuyển đổi sang NTTS cũng đóng góp từ $60-72 \%$. Điều đáng chú ý, diện tích RNM bị mất đi do sạc lở bờ biển liên tục tăng lên qua các giai đoạn: chiếm $17,1 \%$ tổng diện tích RNM bị mất đi trong giai đoạn 1988-1998, giai đoạn 19982013 tăng lên $19 \%$, và $29,7 \%$ cho giai đoạn 2013 2018.

Bảng 6. Sự chuyển đổi từ RNM sang các loại đất khác giai đoạn 1988-2018

\begin{tabular}{clrrrrr}
\hline \multirow{2}{*}{ TT Huyện } & \multicolumn{4}{c}{ RNM chuyển sang các loại đất khác (ha) } & \multirow{2}{*}{ Tổng } \\
\cline { 2 - 6 } & Đất NN & Mặt nước & NTTS & Đất khác & \\
\hline \multirow{2}{*}{1} & Tân Phú Đông & 6,5 & 343,4 & 765,5 & 0,2 & $1.115,6$ \\
2 & Gò Công Đông & 57,2 & 69,5 & 58,9 & 6,2 & 191,9 \\
\hline & Tồng: & 63,7 & 413,0 & 824,5 & 6,4 & $1.307,6$ \\
& Tỉ lệ (\%) & 4,9 & 31,6 & 63,1 & 0,5 & 100,0 \\
\hline
\end{tabular}


3.2.4. Diện tích RNM được phuc hồi ở tỉnh Tiền Giang giai đoạn 1988-2018

Giai đoạn 1988-2018 diện tích RNM được phục hồi ở Tiền Giang là 1.089 ha, chỉ bằng $83 \%$ tổng diện tích RNM bị mất đi trong giai đoạn này. Tốc độ phục hồi RNM được tính là 36 ha/năm hoặc 2,1\%/năm so với diện tích RNM năm 1988. Tốc độ phục hồi RNM cho các giai đoạn cụ thể 1988-1998, 1998-2013 và 2013-2018 lần lượt là 80 ha/năm, 48 ha/năm và 74 ha/năm (Hình 9).

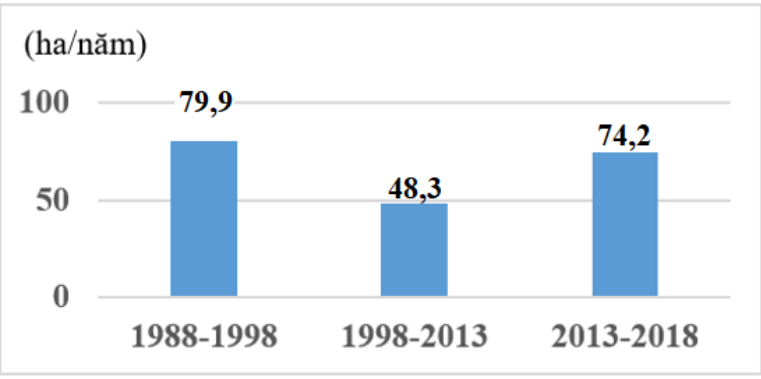

\section{Hình 9. Tốc độ phục hồi RNM tỉnh Tiền Giang qua các giai đoạn}

Nguyên nhân dẫn đến sự phục hồi của RNM: RNM được phục hồi chủ yếu từ mặt nước với 725 ha, chiếm 66,6\% tổng diện tích RNM được phục hồi trong giai đoạn 1988-2018 (mặt nước biển ven bờ năm 1988 nay đã được bồi lắng trầm tích, tạo điều kiện thuận lợi cho RNM phát triển, đặc biệt là RNM được mở rộng ra phía biển ở huyện Tân Phú Đông trên các cồn đất mới nổi). Tiếp đến là việc trồng RNM trong các ao nuôi tôm bị bỏ hoang, hoặc trồng RNM kết hợp với NTTS với diện tích 300 ha, chiếm 27,6\% (Bảng 7). Trong từng giai đoạn cụ thể 19881998, 1998-2013, và 2013-2018, RNM được phục hồi từ mặt nước cũng đóng góp từ 27-65\% tổng diện tích RNM được phục hồi trong từng giai đoạn.

Bảng 7. Phục hồi RNM tỉnh Tiền Giang giai đoạn 1988-2018

\begin{tabular}{clrrrrr}
\hline \multirow{2}{*}{ TT Huyện } & \multicolumn{2}{c}{ Các loại đất khác chuyển sang RNM (ha) } & \multirow{2}{*}{ Tổng } \\
\cline { 2 - 5 } & Đất NN & Mặt nước & NTTS & Đất khác & \\
\hline \multirow{2}{*}{1} & Tân Phú Đông & 46,3 & 594,7 & 28,0 & 0,0 & 668,9 \\
\cline { 2 - 5 } & Gò Công Đông & 16,7 & 131,2 & 272,3 & 0,0 & 420,3 \\
\hline & Tồng: & 63,0 & 725,9 & 300,3 & 0,0 & $1.089,2$ \\
& Tỉ lệ (\%) & 5,8 & 66,6 & 27,6 & 0,0 & 100,0 \\
\hline
\end{tabular}

\subsection{Diện tích RNM không đổi ở tỉnh Tiền} Giang sau 30 năm (1988-2018)

Kết quả chồng xếp bản đồ của các năm 1988 , 1998, 2013 và 2018 đã xác định diện tích RNM không đổi tỉnh Tiền Giang sau 30 năm (1988-2018) là 244 ha, chiếm 15,8\% diện tích RNM năm 2018. Huyện Gò Công Đông có diện tích lớn nhất với 165 ha, chiếm $68 \%$ tổng diện tích RNM không đổi của tỉnh; ngược lại diện tích RNM không đổi của huyện Tân Phú Đông chỉ chiếm 32\%, với 78 ha (Bảng 8).

Bảng 8. Diện tích RNM không đổi tỉnh Tiền Giang sau 30 năm (1988-2018)

\begin{tabular}{llrr}
\hline Tỉnh & Huyện & Diện tích RNM không đổi (ha) & \% so với diện tích RNM năm 2018 \\
\multirow{2}{*}{ Tiền Giang } & Tân Phú Đông & 78,2 & 8,6 \\
& Gò Công Đông & 165,9 & 26,1 \\
\hline \multicolumn{2}{c}{ Tồng: } & 244,1 & 15,8 \\
\hline
\end{tabular}

\section{loại}

\section{4. Đánh giá tỉ lệ chính xác của kết quả phân}

Độ chính xác của kết quả phân loại được thực hiện trên ảnh phân loại năm 2018 , dựa vào kết quả khảo sát thực địa có sự hỗ trợ của GPS (Huynh Thi Cam Hong et al., 2020). Việc khảo sát thực địa với 33 điểm mẫu rải đều trên toàn bộ khu vực nghiên cứu, trong đó có 10 điểm là RNM, 4 điểm đất nông nghiệp, 5 điểm mặt nước, 8 điểm nuôi trồng thủy sản và 6 điểm còn lại là đất khác. Kết quả kiểm tra cho thấy với 601 pixel mẫu, số pixel đúng là 468 , số pixel sai là 133 , độ chính xác $77,8 \%$. Chỉ số Kappa tương ứng là 0,71 (Trần Thu Hà et al., 2016; Tôn Sơn et al., 2020) (Bảng 9). Ảnh phân loại năm 1988, 1998, 2013 tác giả không tiến hành đánh giá vì không có dữ liệu để kiểm tra. 
Bảng 9. Độ chính xác của kết quả phân loại năm 2018

\begin{tabular}{|c|c|c|c|c|c|c|c|}
\hline Phân loại & RNM & Đất NN & Mặt nước & NTTS & Đất khác & Tổng & Độ chính xác (\%) \\
\hline RNM & 153 & & & 1 & & 154 & 99,3 \\
\hline Đất NN & & 47 & & & 1 & 48 & 97,9 \\
\hline Mặt nước & & 4 & 48 & 13 & & 65 & 73,8 \\
\hline NTTS & & 56 & 15 & 127 & 5 & 203 & 62,5 \\
\hline Đất khác & 1 & 35 & & 2 & 93 & 131 & 70,9 \\
\hline Tổng & 154 & 142 & 63 & 143 & 99 & 601 & \\
\hline Độ chính xác (\%) & 99,3 & 33,1 & 76,2 & 88,8 & 93,9 & & \\
\hline
\end{tabular}

Chỉ số Kappa tương ứng là 0,71

\section{KẾT LUẬN}

Sử dụng ảnh vệ tinh đa thời gian cho phép đánh giá sự biến động của các yếu tố phân bố theo không gian một cách nhanh chóng và tương đối chính xác, trong đó có sự thay đổi về lớp phủ thực vật, đặc biệt là $\mathrm{RNM}$

Kết quả phân tích cho thấy trong khoảng thời gian 30 năm (1988-2018), diện tích RNM ở tỉnh Tiền Giang giảm 218 ha (giảm 7,3 ha/năm). Tốc độ phục hồi của RNM được xác định là 36 ha/năm, thấp hơn so với tốc độ biến mất của chúng trong thời gian này (43 ha/năm), chỉ có 244 ha RNM không thay đổi. Nguyên nhân chính dẫn đến sự suy giảm diện tích RNM là do sự chuyển đổi từ RNM sang NTTS (chiếm 63,1\%); sạt lở bờ biển (chiếm 31,6\%). RNM được phục hồi chủ yếu từ mặt nước biển ven bờ (chiếm 66,6\%); trồng mới RNM trong các ao nuôi tôm bị bỏ hoang, hoặc trồng RNM kết hợp với NTTS (chiếm 27,6\%).

\section{TÀI LIỆU THAM KHẢO}

Bùi Trọng Vinh (2016). Xói lở bờ biển Gò Công Tiền Giang. Tạp chí phát triển Khoa học và Công nghệ, 19, 59-69.

Huynh T.C.H., Ram A. \& Masahiko F. (2020). Monitoring changes in land use and distribution of mangroves in the southeastern part of the Mekong River Delta, Vietnam. International Society for Tropical Ecology, 1-14.

Nguyễn Hải Hòa \& Nguyễn Văn Quốc (2017). Sử dụng ảnh viễn thám Landsat và GIS xây dựng bản đồ biến động diện tích rừng tại vùng đệm
Vườn quốc gia Xuân Sơn. Tạp chi khoa hoc và công nghẹ, 3, 46-56.

Trần Thị Lợi \& Phạm Minh Cương (2015). Nghiên cưu nguyên nhân suy thoái rùng ngập mặn và các giải pháp công nghệ để trồng rùng ngập mặn ở các tỉnh ven biển bị xói mòn ở đồng bằng sông Cưu Long (trang 222-228). Nhà xuất bản Bộ Nông nghiệp và Phát triển Nông thôn.

Pham H.T., Nguyen T.H.H \& Mai S.T. (2019). Changes of mangrove cover, species composition and sedimentation rate in Xuan Thuy national park, Vietnam. Science on Natural Resources and Environment, 25, 36-40.

Phạm Văn Ngọt (2012). Vai trò của rừng ngập mặn ven biển Việt Nam. Tap chi Khoa học Đại học Su phạm Thành phố Hồ Chí Minh, 33, 115-124.

Tôn Sơn, Trịnh Phi Hoành, Dobrynin D. V \& Mokievsky V. O (2020). Úng dụng ảnh viễn thám Landsat và công nghệ GIS đánh giá biến động diện tích RNM tỉnh Trà Vinh giai đoạn 1988-2018. Tap chi khoa hoc Truòng ĐHSP TP. HCM, 6, 1074-1087.

Trần Thu Hà (2016). Ứng dụng GIS và viễn thám trong giám sát biến động diện tích rừng huyện Cao Phong, tỉnh Hòa Bình giai đoạn 2005-2015. Tạp chí Khoa học và công nghẹ lâm nghiệp, 4, 59-69.

Trần Vũ Khánh Linh, Viên Ngọc Nam (2017). Phân tích diễn biến rừng bằng ảnh viễn thám tại Cồn Ngang, huyện Tân Phú, tỉnh Tiền Giang. Tap chí khoa họ rừng và môi truờng, 81+82, 36-42.

Nardin, W., Locatelli, S., Pasquarella, V., Rulli, M. C., Woodcock, C. E., \& Fagherazzi, S. (2016). Dynamics of a fringe mangrove forest detected by Landsat images in the Mekong River Delta, Vietnam. Earth Surface Processes and Landforms, 41(14), 2024-2037. 